\title{
Bioinformatic Analysis of Antiviral Medicinal Compounds Against Sars Cov-2 Proteases
}

\author{
Fahad Hassan Shah ${ }^{1}$, Kyeong Ho Lim², Song Ja Kim ${ }^{1, *}$ \\ ${ }^{1}$ Dept. of Biological Sciences, College of Natural Sciences, Kongju National University, Gongju \\ 32588, Republic of Korea. ${ }^{2}$ Department of Civil and Environmental Engineering, College of \\ Engineering, Kongju National University, Cheonan 31080, Republic of Korea \\ *Corresponding author:ksj85@kongju.ac.kr
}

\begin{abstract}
The world is under siege from a global pandemic caused by a novel class of coronaviruses called severe acute respiratory syndrome coronavirus-2 (SARS CoV-2). These viruses cause severe respiratory illness leading to death. Molecular studies reveal that SARS CoV-2 proteases are involved in the processing of viral polyproteins. This study was conducted to obtain antiviral agents for SARS CoV-2 proteases. An extensive library of antiviral medicinal compounds was scrutinized to determine the probable interaction with both main and 3-chymotrypsin like proteases. Six antiviral compounds (Abietic Acid, Gallic Acid, Piceatannol, Piperine, Sinomenine, and Triptolide) were capable of establishing hydrogen bonds with the active pocket residues of the viral proteases, with appreciable binding energy. These compounds were subjected to root mean square analysis and tested not only for acute toxicity, but also for absorption, distribution, metabolism, excretion, and toxicity properties. Results were favourable for use in the treatment of SARS COV-2 infection.
\end{abstract}

Keywords: Severe acute respiratory syndrome coronavirus-2; virtual Screening; antiviral Medicinal Compounds; viral Proteases; ADMET Properties

\section{Introduction}

An unprecedented surge of severe acute respiratory syndrome coronavirus- 2 is currently being observed worldwide. There are millions of infected individuals and several thousand impending deaths. It was first reported in Wuhan, China during the Chinese New Year, and it turned into a global pandemic due to its unfamiliar nature and subclinical manifestation. Symptoms include a high fever, dry cough, convulsions, headaches, sore throat, loss of taste or smell, muscle pain, and lymphopenia. Severe respiratory distress can be observed due to lung consolidation inflicting physiological failure. An individual infected with this virus remains asymptomatic for a long time, hence acting as a vector for disease transmission (Bai et al., 2020; Lai et al., 2020). The mortality rate ranges from $4-6 \%$ but this number dramatically increases in the elderly as well as in the people with underlying secondary illnesses or immune conditions. Preliminary studies assumed that these viruses derive from bats and are transmitted to humans through critical mutational events and possibly through palm civets as intermediate hosts (Zhou et al., 2020). However, the ancestor of this virus is still unknown, and many studies are underway in order to establish the possible leads.

Severe acute respiratory syndrome coronavirus 2 is a member of genus Betacoronavirus, family Coronaviridae, suborder Cornidovirineae, order Nidovirales, and realm Riboviria (Nand et al., 2020). The members of this group are notorious for causing severe respiratory distress in humans and animals. These viruses are composed of positive-sense, single-stranded RNA, enclosed within a lipid envelope. Upon infection, the spikes protruding from the virion 
impersonate typical eukaryotic mRNA, with their 5'cap and poly-A tails (Kang et al., 2020). The virion is about 60-160 nm in size, and the genomic sequence has about 19-32 kilobase pairs. The SARS-COV-2 genome possesses 14 annotated open reading frames, which are readily translated by the host ribosome in order to produce viral polyproteins (Kaul, 2020). These polyproteins are further processed by two cysteine proteases 3C-like protease and main-like protease encoded by ORF1a of SARS COV-2 RNA (Báez-Santos et al., 2015; Jo et al., 2020). These proteases together facilitate the proteolytic processing of polyproteins into respective protein monomers, and are considered essential molecular drug targets in order to avert viral propagation.

Medicinal compounds are well known for a multitude of pharmacological activity against various types of diseases. However, recent reports highlighted their antiviral activity, including substantial viral load reduction and immunological stimulation toward viral antigens (BenShabat et al., 2019). Such compounds could be promising medications for the treatment of this debilitating disease. In this study, we opted for a virtual screening method by employing different antiviral medicinal compounds. We were able to determine the probable interaction of the antiviral compounds with these viral proteases and assess the ADMET profile and possible adverse effects of these compounds, in order to expedite the discovery of drugs.

\section{Methodology}

\subsection{Prediction of Active Site Residues}

Two structural proteases of SARS COV-2, the COVID main-protease (6LU7) (Jo et al., 2020)and 3-chymotrypsin-like protease (4WY3) (Jin et al., 2020), known for their proteolytic processing of viral polyproteins, were chosen as target receptors and procured from the Protein data bank. Active site pocket residues were identified through Metapocket 2.0, to highlight the potential ligand-binding sites (Zhang et al., 2011).

\subsection{Preparation of Ligands and Receptors}

A library of ligands was prepared by selecting antiviral medicinal compounds as discussed in the study (Ben-Shabat et al., 2019). Receptors and ligands were appropriately prepared with the Modrefiner(Xu et al., 2011)and PRODRG servers (Schüttelkopf et al., 2004) and then subjected to virtual screening using Autodock Vina equipped with Raccoon2 plugin.

\subsection{Docking Validation}

The validation of our screening method was confirmed by re-docking $\mathrm{N}-[(5-$ Methylisoxazol-3-Y1)Carbonyl]Alanyl-L-Valyl-N 1 -((1R,2Z)-4-(Benzyloxy)-4-Oxo-1-\{[(3R)2-Oxopyrrolidin-3-Yl]Methyl $\}$ But-2-Enyl)-L-Leucinamide and (2S)-2-(\{[(3R,4aS,8aR)-2(biphenyl-4-ylcarbonyl)decahydroisoquinolin-3-yl]methyl amino)-3-(1H-imidazol-5-yl)propanal into their original active sites in these receptors.

\subsection{Docking Stability and ADMET Analysis}

Efficiently interacted ligands were further analyzed for the root mean square deviation, using LigRMSD, acute toxicity and adverse effects through the GUSAR and Adver-Pred databases. 
ADMET properties were predicted with Swiss ADME, ADMET SAR 2.0 and pKCSM (Lagunin et al., 2011; Pires et al., 2015; Daina et al., 2017; Ivanov et al., 2018; Yang et al., 2019; Velázquez-Libera et al., 2020).

\section{Results}

\subsection{Screening, Validation and Stability Analysis}

Molecular docking is a bioinformatic modeling algorithm that is employed for drug discovery purposes. This technique determines the possible interaction and binding mode of a ligand with the target receptor. Docking validation of our virtual screening parameters successfully docked the original ligands of main protease and 3CL protease into their aboriginal position, which further paved the way to commence our screening study.

In this study, we selected two SARS COV-2 proteases as receptors, and the ligands were antiviral medicinal compounds. Both ligands and receptors were refined and minimized through PRODRG (Schüttelkopf et al., 2004) and Modrefiner (Xu et al., 2011). The active site of these receptors was scrutinized with Metapocket 2.0 (Zhang et al., 2011) to identify the possible active amino acid residues within these viral proteins. Docking interaction was performed through Raccoon2, a virtual screening platform of Autodock vina to analyze an extensive library of antiviral medicinal compounds against SARS COV-2 proteases. These ligands were converged at the active site to determine their interaction with the active residues of these viral receptors (Supplementary Table 1). The results obtained from the docking study were analyzed based on the hydrogen bonding of the ligands with active residues of receptors and low binding energy. Interaction with anything other than the predicted active site was omitted. Six promising drug candidates (Abietic Acid, Gallic Acid, Piceatannol, Piperine, Sinomenine, and Triptolide) formed hydrogen bonds with the active residues of these viral receptors (Figure 1 and Supplementary Figure 1). Furthermore, these compounds exploited their hydroxy along with oxygen groups $(=\mathrm{O},-\mathrm{O})$ to form hydrogen bonds with the active site of these receptors (Figure 2 and Supplementary Figure 2). Some ligands shared a chemical affinity for the active site residues of viral receptors, which is a strong indicator of similar activity. Active site residues of 4WY3, such as ASP153, were used by Abietic Acid, Gallic Acid, and Piceatannol whereas GLN110 was used by Gallic Acid, Piceatannol and Sinomenine. ASN151 was the binding residue for Gallic Acid and Triptolide, whereas Sinomenine, and Gallic Acid both used THR292 for interaction. Among all these ligands, Gallic Acid, Sinomenine, and Piceatannol were found to be more active in establishing hydrogen bonds with the active pocket of 4WY3 protease. A similar type of binding interaction was also observed for 6LU7 protease. TYR54, GLY143, CYS145, and ASN145 were the common active residues exploited by these compounds for interaction. Among them, Triptolide was the only candidate active against 6LU7 protease in terms of hydrogen bonds. Further stability studies revealed that all of these successful ligands had a low binding energy and minimal RMSD values (1.01-2.79 $\AA$ ), suggesting a stable adduct, in line with the reported studies (Ding et al., 2016; Xiao et al., 2018). The complete docking results are summarized in Table 1.

\subsection{Acute Toxicity and Adverse Effects}

Acute toxicity and adverse effect prediction were carried out to determine the lethality and adverse effect profile of these compounds. These compounds incite toxicity at $>11,000 \mathrm{mg} / \mathrm{kg}$ 
through the intravenous route, and $>100,000 \mathrm{mg} / \mathrm{kg}$ for the oral route. Most of these compounds were classified as class 3 chemicals in terms of toxicity except for Gallic acid and Piceatannol, which were class 5 , according to the OECD report. The probable side effects of these compounds were relatively low, as evident in their Pa value $(<0.7)$ (Khanal et al., 2019). Rare side effects include hepatotoxicity, arrhythmia, and myocardial infarction. The results of acute toxicity and adverse effects of these compounds are depicted in Table 2 and Table 3.

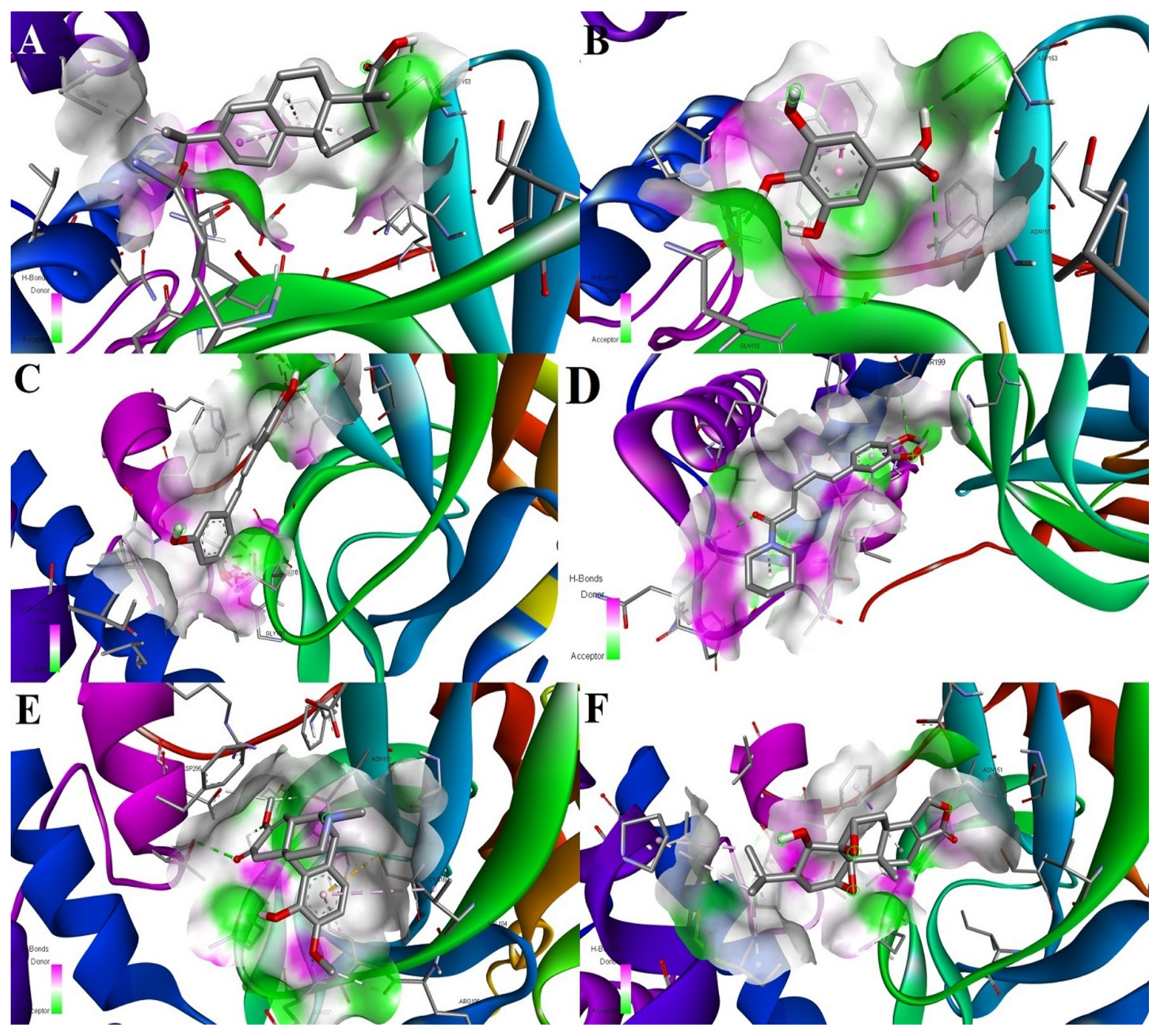

Fig.1. 3D Docked Structures of 3CL like Proteases of SARS COV-2 with Antiviral Medicinal Compounds. A) Abietic Acid, B) Gallic Acid, C) Piceatannol. D) Piperine, E) Sinomenine, F) Triptolide 

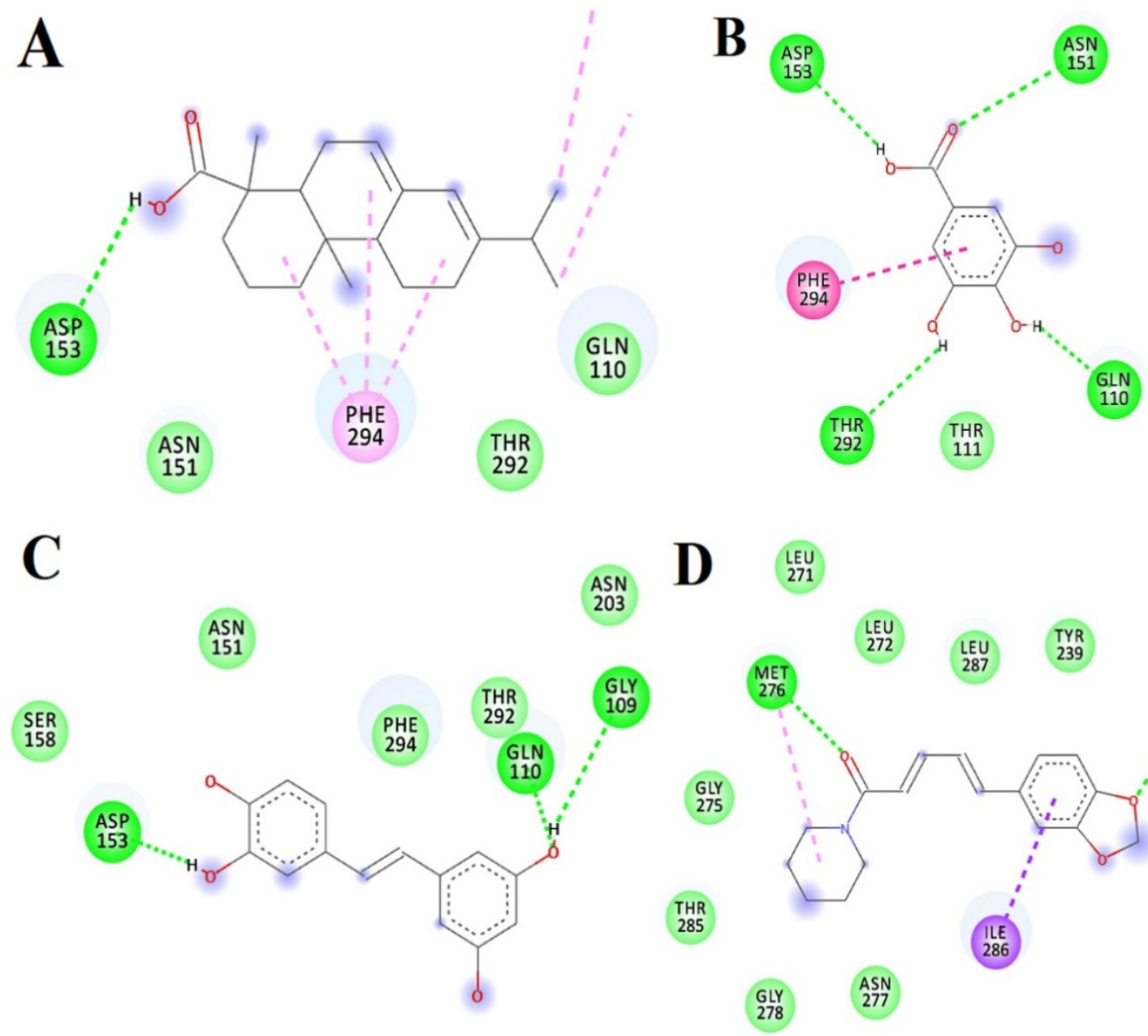

D
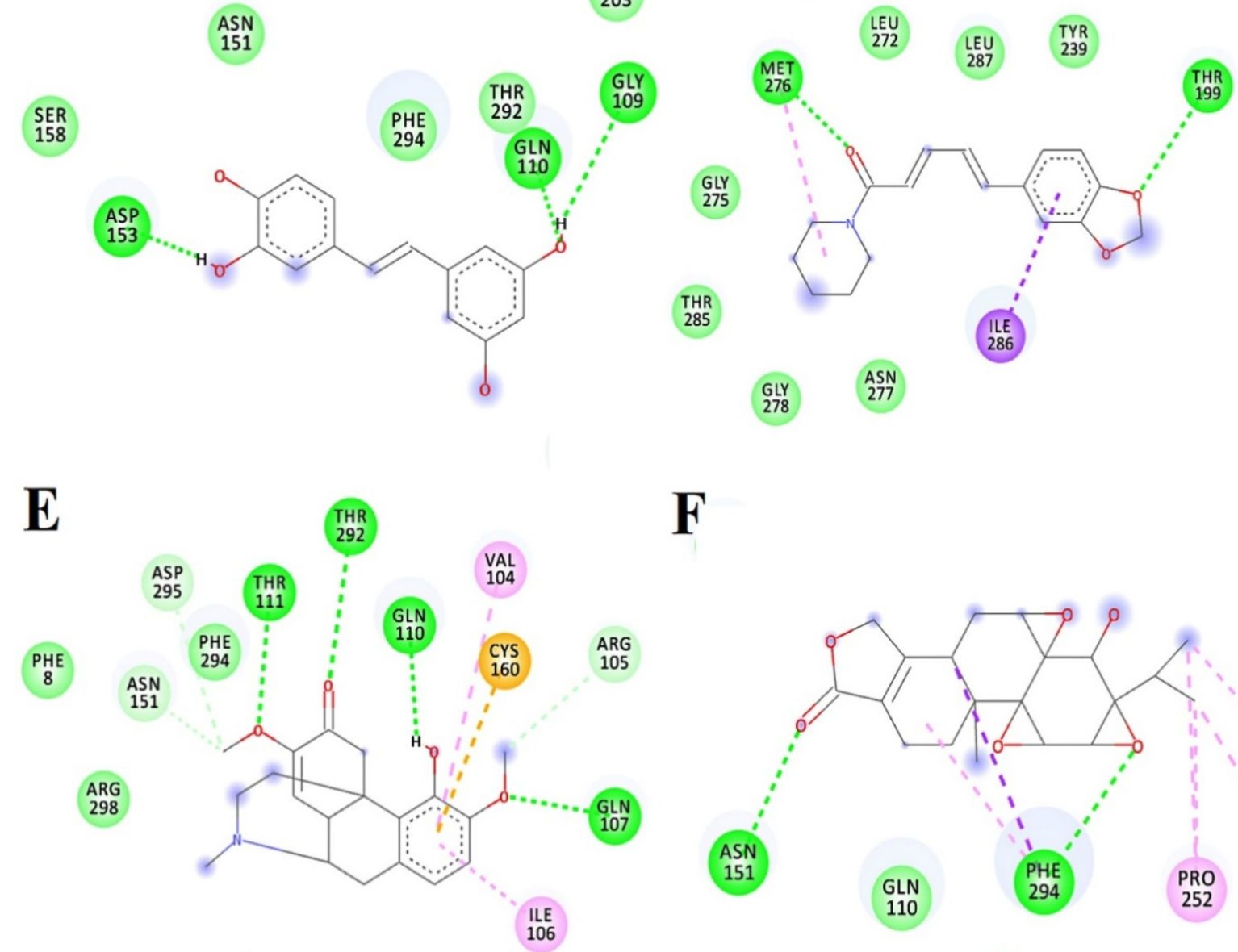

F

$\begin{array}{ll}\text { SER } & \text { AS } \\ 158 & 153\end{array}$

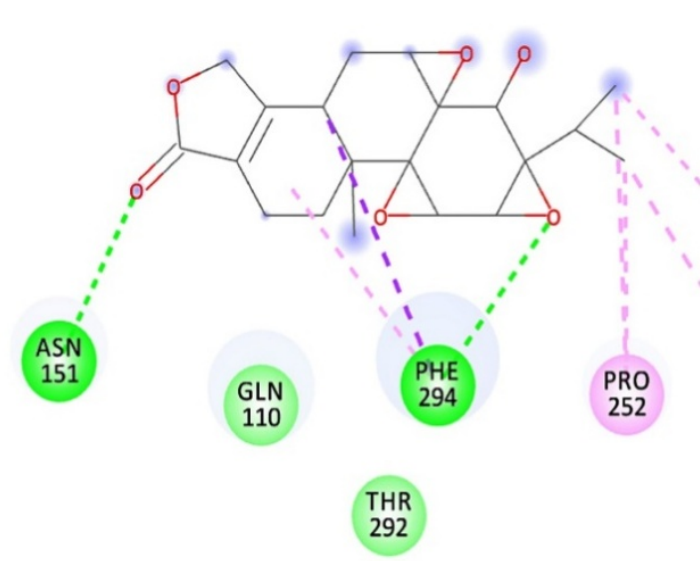

Fig. 2. Structural Visualization of Antiviral Medicinal Compounds interaction with $3 \mathrm{CL}$ like Proteases of SARS COV-2 A) Abietic Acid, B) Gallic Acid, C) Piceatannol. D) Piperine, E) Sinomenine, F) Triptolide 
Table 1. Docking Analysis of Ligands Establishing Hydrogen Bonds with the Active site of Target Viral Receptors

\begin{tabular}{|c|c|c|c|c|c|}
\hline Ligands & $\begin{array}{l}\text { Receptor } \\
\text { (PDB ID) }\end{array}$ & $\begin{array}{l}\text { Active Site Subunits } \\
\text { (Predicted) }\end{array}$ & $\begin{array}{c}\text { Ligands } \\
\text { Hydrogen } \\
\text { Interaction } \\
\text { with } \\
\text { Receptor } \\
\text { Active } \\
\text { Residues }\end{array}$ & LigRMSD(A) & $\begin{array}{c}\text { Binding } \\
\text { Energy } \\
(\text { Kcal } / \mathbf{m o l})\end{array}$ \\
\hline Abietic Acid & SARS- & LEU202, LEU242, & ASP153 & 1.53 & -7.2 \\
\hline Gallic Acid & $\begin{array}{c}\mathrm{CoV} \\
\text { Peptidase } \\
(2 \mathrm{GTB})\end{array}$ & $\begin{array}{l}\text { ASP245, ILE249, } \\
\text { ASP248, PRO241, } \\
\text { THR243, GLN110, } \\
\text { PRO108, GLU240, }\end{array}$ & $\begin{array}{l}\text { GLN110, } \\
\text { ASN151, } \\
\text { ASP153, } \\
\text { THR292 }\end{array}$ & 1.96 & -5.5 \\
\hline Piceatannol & & $\begin{array}{l}\text { GLY109, ILE200, } \\
\text { ASN203, PRO132, } \\
\text { GLN107, THR111, } \\
\text { ASN151. THR292. }\end{array}$ & $\begin{array}{l}\text { GLY109, } \\
\text { GLN110, } \\
\text { ASP153 }\end{array}$ & 1.72 & -6.6 \\
\hline Piperine & & $\begin{array}{l}\text { PHE294, ASP295, } \\
\text { ARG298, ILE106, }\end{array}$ & $\begin{array}{l}\text { THR 199, } \\
\text { MET276 }\end{array}$ & 1.65 & -6.7 \\
\hline Sinomenine & & $\begin{array}{l}\text { CYS160, VAL104, } \\
\text { ARG105, SER158, } \\
\text { ASP153, ILE152, } \\
\text { CYS156, PHE08, }\end{array}$ & $\begin{array}{l}\text { GLN107, } \\
\text { GLN110, } \\
\text { THR111, } \\
\text { THR292 }\end{array}$ & 1.46 & -7.0 \\
\hline Triptolide & & $\begin{array}{l}\text { GLN127, PRO293, } \\
\text { LYS102, VAL297, } \\
\text { PRO252, THR199, } \\
\text { ASP155, LEU253 }\end{array}$ & $\begin{array}{l}\text { ASN151, } \\
\text { PHE294 }\end{array}$ & 1.15 & -7.6 \\
\hline Abietic Acid & COVID-19 & LEU141, ASN142, & ASN142 & 1.06 & -5.9 \\
\hline Gallic Acid & $\begin{array}{l}\text { Main } \\
\text { protease } \\
(6 \mathrm{LU} 7)\end{array}$ & $\begin{array}{l}\text { CYS145, HIS163, } \\
\text { MET165, GLU166, } \\
\text { HIS41, THR25, HIS164, }\end{array}$ & $\begin{array}{l}\text { LEU141, } \\
\text { CYS145, } \\
\text { GLU166 }\end{array}$ & 2.79 & -4.9 \\
\hline Piceatannol & & $\begin{array}{l}\text { ASP187, ARG188, } \\
\text { GLN189, TYR54, } \\
\text { MET49, CYS44, } \\
\text { PRO52, GLN192, }\end{array}$ & $\begin{array}{l}\text { ASN53, } \\
\text { TYR54, } \\
\text { GLU55 }\end{array}$ & 1.67 & -5.7 \\
\hline Piperine & & GLY143, THR25, & TYR54 & 1.68 & -6.1 \\
\hline Sinomenine & & $\begin{array}{l}\text { LEU27, THR26, } \\
\text { SER144, LEU167, } \\
\text { PRO168, THR190, }\end{array}$ & $\begin{array}{l}\text { GLY143, } \\
\text { CYS145, } \\
\text { GLN189 }\end{array}$ & 1.13 & -6.0 \\
\hline Triptolide & & $\begin{array}{c}\text { PHE140, HIS172, } \\
\text { ALA191, TYR118, } \\
\text { THR24, ASN119, } \\
\text { THR45, THR24, SER46, } \\
\text { ASP48, ALA193, } \\
\text { LEU50, ASN51, } \\
\text { VAL42, GLU47, THR26 }\end{array}$ & $\begin{array}{l}\text { THR25, } \\
\text { ASN142, } \\
\text { GLY143, } \\
\text { CYS145 }\end{array}$ & 1.01 & -7.5 \\
\hline
\end{tabular}


Table 2. Toxicity and Chemical Profile of Successful Antiviral Medicinal compounds

\begin{tabular}{ccccc}
\hline No. & Compounds & $\begin{array}{c}\text { IV LD50 } \\
\text { (mg/kg) }\end{array}$ & $\begin{array}{c}\text { Oral LD50 } \\
(\mathbf{m g} / \mathbf{k g})\end{array}$ & $\begin{array}{c}\text { Toxicity Classification by OECD } \\
\text { Project }\end{array}$ \\
\hline 1 & Abietic Acid & 29,250 & $2,287,000$ & Class 3 Chemicals \\
2 & Gallic Acid & 465,900 & $1,606,000$ & Class 5 Chemicals \\
3 & Piceatannol & 150,700 & $2,571,000$ & Class 5 Chemicals \\
4 & Piperine & 33,950 & 861,000 & Class 3 Chemicals \\
5 & Sinomenine & 32,450 & 203,000 & Class 3 Chemicals \\
6 & Triptolide & 11,100 & 140,700 & Class 3 Chemicals \\
\hline
\end{tabular}

Table 3. Rare Adverse effects of Successful Antiviral Medicinal Compounds; *Pa: Probability of activity, Pi: Probability of inactivity

\begin{tabular}{lllll}
\hline No & Compounds & Pa Value & Pi Value & Side Effects \\
\hline 1 & Abietic Acid & 0.941 & 0.004 & Myocardial infarction \\
2 & Gallic Acid & 0.699 & 0.101 & Hepatotoxicity \\
3 & Piceatannol & 0.314 & 0.282 & Arrhythmia \\
4 & Piperine & 0.556 & 0.167 & Hepatotoxicity \\
5 & Sinomenine & 0.453 & 0.146 & Arrhythmia \\
6 & Triptolide & 0.302 & 0.193 & Myocardial infarction \\
\hline
\end{tabular}

\subsection{ADMET Properties}

To determine the nature and behavior of these compounds inside an organism, it is necessary to ascertain their adsorption, distribution, metabolism, excretion, and toxicity (ADMET), prior to animal and clinical studies (Table 4). These selected medicinal compounds possess a high GI absorption with active oral bioavailability, apart from Piceatannol and Sinomenine whereas Gallic Acid lacks Caco-2 permeability. High BBB penetration was reported for Abietic acid, Sinomenine, Triptolide, and Piperine, while Piperine, Piceatannol, and Sinomenine were potential substrates for P-Glycoprotein. Only Piperine had the capability to inhibit P- Glycoprotein-I. Abietic acid, Sinomenine, and Triptolide were CYP3A4 substrates, and Piperine and Piceatannol were CYP2C9 substrates. CYP2C19 was efficiently inhibited by Abietic acid, Piperine, and Piceatannol, but CYP2D6 and CYP1A2 were only inhibited by Piceatannol. Sinomenine only inhibited CYP2D6. Gallic Acid was the only compound that showed no interaction with any CYP variant. The highest total clearance was noted for Sinomenine and Abietic acid, and the lowest was observed for Piperine. Possible substrates for Renal OCT2 were Abietic acid, Piperine, and Sinomenine. 
Table 4. ADMET and Druglikeness Properties of Successful Antiviral Medicinal Plants. *CYP: Cytochromes P450, hERG: human Ether-à-go-go-Related Gene, BBB: Blood-Brain Barrier, OCT2: Organic Cation Transporter-2,Caco-2 cells: human colon epithelial cancer cell line,.X means no activity and $\checkmark$ means activity.

\begin{tabular}{|c|c|c|c|c|c|c|}
\hline ADMET Parameters & $\begin{array}{l}\text { Compounds } \\
\text { Abietic Acid }\end{array}$ & Gallic Acid & Piceatannol & Piperine & Sinomenine & Triptolide \\
\hline ABSORPTION & & & & & & \\
\hline $\begin{array}{l}\text { Human } \\
\text { Absorption }\end{array}$ & High & High & High & High & High & High \\
\hline $\begin{array}{ll}\text { Human } & \text { oral } \\
\text { bioavailability } & \end{array}$ & High & High & High & High & High & High \\
\hline Caco-2 Permeability & High & Low & High & High & High & High \\
\hline Water solubility & Soluble & Soluble & Soluble & Soluble & Soluble & Soluble \\
\hline $\begin{array}{l}\text { Subcellular } \\
\text { Localization }\end{array}$ & Mitochondria & Mitochondria & Mitochondria & Mitochondria & Mitochondria & Mitochondria \\
\hline $\begin{array}{l}\text { Skin Permeability (Log } \\
\mathrm{Kp} \text { ) }\end{array}$ & $-4.75 \mathrm{~cm} / \mathrm{s}$ & $-6.84 \mathrm{~cm} / \mathrm{s}$ & $-5.76 \mathrm{~cm} / \mathrm{s}$ & $-5.58 \mathrm{~cm} / \mathrm{s}$ & $-6.78 \mathrm{~cm} / \mathrm{s}$ & $-8.34 \mathrm{~cm} / \mathrm{s}$ \\
\hline DISTRIBUTION & & & & & & \\
\hline $\begin{array}{l}\text { P-glycoprotein } \\
\text { substrate }\end{array}$ & $\mathrm{X}$ & $\mathrm{x}$ & $\checkmark$ & $\checkmark$ & $\checkmark$ & $\mathrm{x}$ \\
\hline $\begin{array}{l}\text { P-glycoprotein } \\
\text { inhibitor }\end{array}$ & $\mathrm{X}$ & $\mathrm{x}$ & $\mathrm{X}$ & $\checkmark$ & $\mathrm{x}$ & $\mathrm{x}$ \\
\hline $\begin{array}{l}\text { P-glycoprotein II } \\
\text { inhibitor }\end{array}$ & $\mathrm{X}$ & $\mathrm{x}$ & $\mathrm{X}$ & $\mathrm{x}$ & $\mathrm{x}$ & $\mathrm{x}$ \\
\hline $\begin{array}{l}\text { BBB permeability } \\
\text { METABOLISM }\end{array}$ & $\checkmark$ & $\mathrm{x}$ & $\mathrm{X}$ & $\checkmark$ & $\checkmark$ & $\checkmark$ \\
\hline CYP2D6 substrate & $\mathrm{X}$ & $\mathrm{x}$ & $\mathrm{X}$ & $\mathrm{x}$ & $\checkmark$ & $\checkmark$ \\
\hline CYP3A4 substrate & $\checkmark$ & $\mathrm{X}$ & $\checkmark$ & $\checkmark$ & $\mathrm{x}$ & $\mathrm{x}$ \\
\hline CYP1A2 inhibitor & $\mathrm{X}$ & $\mathrm{X}$ & $\checkmark$ & $\mathrm{x}$ & $\mathrm{x}$ & $\mathrm{X}$ \\
\hline CYP2C19 inhibitor & $\checkmark$ & $\mathrm{X}$ & $\checkmark$ & $\checkmark$ & $\mathrm{X}$ & $\mathrm{X}$ \\
\hline CYP2C9 inhibitor & $\checkmark$ & $\mathrm{X}$ & $\mathrm{X}$ & $\mathrm{X}$ & $\mathrm{X}$ & $\mathrm{X}$ \\
\hline CYP2D6 inhibitor & $\mathrm{X}$ & $\mathrm{X}$ & $\checkmark$ & $\mathrm{X}$ & $\checkmark$ & $\mathrm{X}$ \\
\hline $\begin{array}{l}\text { CYP3A4 inhibitor } \\
\text { EXCRETION }\end{array}$ & $\mathrm{X}$ & $\mathrm{X}$ & $\mathrm{X}$ & $\mathrm{x}$ & $\mathrm{x}$ & $\mathrm{x}$ \\
\hline $\begin{array}{l}\text { Total Clearance (log } \\
\mathrm{ml} / \mathrm{min} / \mathrm{kg} \text { ) }\end{array}$ & 0.915 & 0.518 & 0.484 & 0.232 & 0.955 & 0.484 \\
\hline $\begin{array}{l}\text { Renal OCT2 substrate } \\
\text { TOXICITY }\end{array}$ & $\checkmark$ & $\mathrm{x}$ & $\mathrm{X}$ & $\checkmark$ & $\checkmark$ & $\mathrm{x}$ \\
\hline AMES toxicity & $\mathrm{X}$ & $\mathrm{X}$ & $\mathrm{X}$ & $\mathrm{X}$ & $\mathrm{X}$ & $\mathrm{X}$ \\
\hline Hepatotoxicity & $\mathrm{X}$ & $\mathrm{X}$ & $\mathrm{X}$ & $\mathrm{X}$ & $\mathrm{X}$ & $\mathrm{X}$ \\
\hline hERG Inhibition & $\mathrm{X}$ & $\mathrm{X}$ & $\mathrm{X}$ & $\mathrm{X}$ & $\mathrm{X}$ & $\mathrm{X}$ \\
\hline Eye irritation & $\mathrm{X}$ & $\mathrm{x}$ & $\mathrm{X}$ & $\mathrm{X}$ & $\mathrm{x}$ & $\mathrm{x}$ \\
\hline Carcinogenicity & $\mathrm{X}$ & $\mathrm{X}$ & $\mathrm{X}$ & $\mathrm{x}$ & $\mathrm{X}$ & $\mathrm{X}$ \\
\hline BIOAVAILABILITY A & ND DRUGLIK & ESS & & & & \\
\hline Bioavailability Score & 0.56 & 0.56 & 0.55 & 0.55 & 0.55 & 0.55 \\
\hline Lipinski & $\begin{array}{l}\text { Yes; } \\
\text { Violation }\end{array}$ & $\begin{array}{l}\text { Yes; } \\
\text { violation }\end{array}$ & $\begin{array}{l}\text { Yes; } \\
\text { violation }\end{array}$ & $\begin{array}{l}\text { Yes; } \\
\text { violation }\end{array}$ & $\begin{array}{l}\text { Yes; } \\
\text { violation }\end{array}$ & $\begin{array}{l}\text { Yes; } \\
\text { violation }\end{array}$ \\
\hline
\end{tabular}




\section{Discussion}

SARS COV-2 is spreading rapidly all over the world in a similar way to the 1918 influenza pandemic with its enigmatic disease nature, elevated risk of transmission, and high morbidity and mortality rates (Yang et al., 2020). There are currently no universally approved medications available to treat this infection. However, the World Health Organization approved Chloroquine and Hydroxychloroquine for SARS COV-2 treatment (Abd El-Aziz et al., 2020), while Gilead Sciences proposed the potential benefits of Remdesivir to expedite patient recovery (Kaul, 2020) These drugs employed for the treatment of SARS COV-2 showed promising results in in vitro studies, but cause a life-threatening array of adverse effects, including hepatotoxicity (Amirian et al., 2020), neurological, and cardiovascular impairment (Devaux et al., 2020). In addition, these novel viruses possess 3'-5' exonuclease protein (ExoN) which weakens the effects of different nucleoside analogue drugs, by a proofreading mechanism (Sevajol et al., 2014). Therefore, there is no option but to search for promising drug candidates, which suppress rapid disease proliferation. Our study attempted to scrutinize various antiviral medicinal compounds for their probable interaction with SARS COV-2 proteases.

Screening analysis filtered six promising ligands as potential drug candidates. These drug candidates employed their oxygen and hydroxyl groups to form hydrogen bonds with the active residues of the viral proteases, whereas carbon rings and other oxy groups established hydrophobic connections to stabilize the docked complex. The formation of hydrogen bonds with the active pocket by the ligand caused functional alterations in the target viral receptor, hence disrupting their enzymatic activity, as evident from the following study (Pandey et al., 2019). Moreover, hydrogen bonding amplifies the binding strength of ligand attachment to the receptor, compared to other types of bonds (Raschka et al., 2018). Further molecular studies revealed that most of these compounds had RMSD values within 1.01-2.79 $\AA$, reflecting coherence between experimentally solved structures and the predicted ligand conformation at the microscopic level as obtained from docking interaction (Ding et al., 2016). In addition, these compounds have low acute toxicity, which means high doses are required to incite toxicity and adverse reactions.

\section{Conclusion}

Screening results revealed six promising compounds with an efficient chemical affinity for SARS COV-2 viral proteases. These compounds have good ADMET properties and low acute toxicities and could be subjected to further in vitro studies in order to confirm their therapeutic efficacy against this disease. The current study provided a small number of lead compounds which showed encouraging interactions with the target viral proteins of SARS COV2. Moreover, we also elucidated the mechanism of action and pharmacokinetic profile of these compounds that might be useful for other researchers searching for potential therapies for this disease.

\section{ACKNOWLEDGMENTS}

This work was supported by the National Research Foundation of Korea (NRF) funded by the Korean Government (MEST) (2020R1I1A3069699). 


\section{References}

Abd El-Aziz, T. M.; Stockand, J. D., (2020).Recent progress and challenges in drug development against COVID-19 coronavirus (SARS-CoV-2) - an update on the status. Infection, Genetics and Evolution, 83: 104327.

Amirian, E. S.; Levy, J. K., (2020). Current knowledge about the antivirals remdesivir (GS5734) and GS-441524 as therapeutic options for coronaviruses. One health, 9: 100128.

Báez-Santos, Y. M.; St. John, S. E.; Mesecar, A. D., (2015). The SARS-coronavirus papainlike protease: Structure, function and inhibition by designed antiviral compounds. Antiviral Research, 115: 21-38.

Bai, Y.; Yao, L.; Wei, T.; Tian, F.; Jin, D. Y. et al., (2020).Presumed asymptomatic carrier transmission of COVID-19. Jama, 323(14): 1406-1407.

Ben-Shabat, S.; Yarmolinsky, L.; Porat, D.; Dahan, A., (2019).Antiviral effect of phytochemicals from medicinal plants: Applications and drug delivery strategies. Drug Delivery and Translational Research, 10(2), 354-367.

Chen, Y.; Yang, C.; Jin, N.; Xie, Z.; Fei, L. et al., (2007). Sinomenine promotes differentiation but impedes maturation and co-stimulatory molecule expression of human monocyte-derived dendritic cells. International immunopharmacology, 7(8): 1102-1110.

Daina, A.; Michielin, O.; Zoete, V., (2017). SwissADME: a free web tool to evaluate pharmacokinetics, drug-likeness and medicinal chemistry friendliness of small molecules. Scientific Reports, 7(1): 42717.

Devaux, C. A.; Rolain, J. M.; Colson, P.; Raoult, D., (2020).New insights on the antiviral effects of chloroquine against coronavirus: what to expect for COVID-19? International Journal of Antimicrobial Agents, 55(5), 105938.

Ding, Y.; Fang, Y.; Moreno, J.; Ramanujam, J.; Jarrell, M.et al., (2016). Assessing the similarity of ligand binding conformations with the Contact Mode Score. Computational biology and chemistry, 64: 403-413.

Gonçalves, J. L. S.; Lopes, R. C.; Oliveira, D. B.; Costa, S. S.; Miranda, M. et al., (2005). In vitro anti-rotavirus activity of some medicinal plants used in Brazil against diarrhea. Journal of ethnopharmacology, 99(3): 403-407.

Ivanov, S. M.; Lagunin, A. A.; Rudik, A. V; Filimonov, D. A.; Poroikov, V. V, (2018).ADVERPred-Web service for prediction of adverse effects of drugs. Journal of chemical information and modeling, 58(1): 8-11.

Jin, Z.; Du, X.; Xu, Y.; Deng, Y.; Liu, M. et al., (2020). Structure of Mpro from COVID-19 virus and discovery of its inhibitors. Nature,582, 289-293.

Jo, S.; Kim, S.; Shin, D. H.; Kim, M. S., (2020). Inhibition of SARS-CoV 3CL protease by flavonoids. Journal of enzyme inhibition and medicinal chemistry, 35(1): 145-151. 
Kang, S.; Peng, W.; Zhu, Y.; Lu, S.; Zhou, M. et al., (2020). Recent progress in understanding 2019 novel coronavirus (SARS-CoV-2) associated with human respiratory disease: detection, mechanisms and treatment. International Journal of Antimicrobial Agents, 55(5), 105950.

Kratz, J. M.; Andrighetti-Fröhner, C. R.; Kolling, D. J.; Leal, P. C.; Cirne-Santos, C. C. et al., (2008).Anti-HSV-1 and anti-HIV-1 activity of gallic acid and pentyl gallate. Memorias do Instituto Oswaldo Cruz, 103(5): 437-442.

Lagunin, A.; Zakharov, A.; Filimonov, D.; Poroikov, V., (2011). QSAR modelling of rat acute toxicity on the basis of PASS prediction. Molecular informatics, 30(2-3): 241-250.

Nand, M.; Maiti, P.; Joshi, T.; Chandra, S.; Pande, V. et al., (2020).Virtual screening of antiHIV1 compounds against SARS-CoV-2: machine learning modeling, chemoinformatics and molecular dynamics simulation based analysis. Scientific Reports, 10(1): 20397.

Pandey, S. K.; Yadav, S.; Goel, Y.; Temre, M. K.; Singh, V. K. et al., (2019). Molecular docking of anti-inflammatory drug diclofenac with metabolic targets: Potential applications in cancer therapeutics. Journal of theoretical biology, 465: 117-125.

Akram, M.; Tahir, I. M.; Shah, S. M. A.; Mahmood, Z.; Altaf, A.et al., (2018). Antiviral potential of medicinal plants against HIV, HSV, influenza, hepatitis, and coxsackievirus: A systematic review. Phytotherapy Research, 32(5): 811-822.

Caesar, L. K.; Cech, N. B., (2019).Synergy and antagonism in natural product extracts: when 1 +1 does not equal 2. Natural Product Reports., 36(6): 869-888.

Hussain, W.; Haleem, K. S.; Khan, I.; Tauseef, I.; Qayyum, S. et al., (2017).Medicinal plants: a repository of antiviral metabolites. Future Virology, 12(6): 299-308.

Jantan, I.; Ahmad, W.; Bukhari, S. N. A., (2015). Plant-derived immunomodulators: an insight on their preclinical evaluation and clinical trials. Frontiers in plant science, 6: 655.

Kaul, D., (2020). An overview of coronaviruses including the SARS-2 coronavirus - Molecular biology, epidemiology and clinical implications. Current Medicine Research and Practice, 10(2): 54-64.

Khanal, P.; Patil, B. M., (2019).Gene set enrichment analysis of alpha-glucosidase inhibitors from Ficus benghalensis. Asian Pacific Journal of Tropical Biomedicine, 9(6): 263.

Lai, C. C.; Liu, Y. H.; Wang, C. Y.; Wang, Y. H.; Hsueh, S. C. et al., (2020).Asymptomatic carrier state, acute respiratory disease, and pneumonia due to severe acute respiratory syndrome coronavirus 2 (SARS-CoV-2): Facts and myths. Journal of Microbiology, Immunology and Infection,53(3):404-12.

Pires, D. E. V; Blundell, T. L.; Ascher, D. B., (2015).pkCSM: predicting small-molecule pharmacokinetic and toxicity properties using graph-based signatures. Journal of medicinal chemistry, 58(9):4066-4072.

Raschka, S.; Wolf, A. J.; Bemister-Buffington, J.; Kuhn, L. A., (2018).Protein-ligand interfaces are polarized: discovery of a strong trend for intermolecular hydrogen bonds to favor 
donors on the protein side with implications for predicting and designing ligand complexes. Journal of Computer-Aided Molecular Design, 32(4): 511-528.

Schüttelkopf, A. W.; Van Aalten, D. M. F., (2004). PRODRG: a tool for high-throughput crystallography of protein-ligand complexes. Acta Crystallographica Section D: Biological Crystallography, 60(8): 1355-1363.

Sevajol, M.; Subissi, L.; Decroly, E.; Canard, B.; Imbert, I., (2014). Insights into RNA synthesis, capping, and proofreading mechanisms of SARS-coronavirus. Virus research, 194: 90-99.

Velázquez-Libera, J. L.; Durán-Verdugo, F.; Valdés-Jiménez, A.; Núñez-Vivanco, G.; Caballero, J., (2020). LigRMSD: a web server for automatic structure matching and RMSD calculations among identical and similar compounds in protein-ligand docking. Bioinformatics, 36(9): 2912-2914.

Wan, Z.; Chen, X., (2014).Triptolide inhibits human immunodeficiency virus type 1 replication by promoting proteasomal degradation of Tat protein. Retrovirology, 11(1): 88.

Xiao, W.; Wang, D.; Shen, Z.; Li, S.; Li, H., (2018).Multi-Body Interactions in Molecular Docking Program Devised with Key Water Molecules in Protein Binding Sites. Molecules, 23(9): 2321.

Xu, D.; Zhang, Y., (2011). Improving the physical realism and structural accuracy of protein models by a two-step atomic-level energy minimization. Biophysical journal, 101(10): 25252534.

Yang, H.; Lou, C.; Sun, L.; Li, J.; Cai, Y.; et al., (2019). admetSAR 2.0: web-service for prediction and optimization of chemical ADMET properties. Bioinformatics, 35(6): 1067-1069.

Yang, Y.; Peng, F.; Wang, R.; Guan, K.; Jiang, T. et al.,(2020). The deadly coronaviruses: The 2003 SARS pandemic and the 2020 novel coronavirus epidemic in China. Journal of Autoimmunity, 109: 102434.

Zhang, Z.; Li, Y.; Lin, B.; Schroeder, M.; Huang, B., (2011). Identification of cavities on protein surface using multiple computational approaches for drug binding site prediction. Bioinformatics, 27(15): 2083-2088.

Zhou, H.; Chen, X.; Hu, T.; Li, J.; Song, H. et al., (2020). A novel bat coronavirus closely related to SARS-CoV-2 contains natural insertions at the $\mathrm{S} 1 / \mathrm{S} 2$ cleavage site of the spike protein.

Current

Biology,

30(11):2196-203.

Submitted: $\quad 28 / 07 / 2021$

Revised: $\quad 25 / 10 / 2021$

Accepted: 28/10/2021

DOI: $10.48129 /$ kjs.splcov. 15451 